\title{
ANALISA ALIRAN ANGIN PADA SUDU TURBIN ANGIN SAVONIUS TIPE-U BERBASIS SOFTWARE
}

\author{
Delffika Canra ${ }^{1}$, Emin Haris ${ }^{2}$, Meri Rahmi ${ }^{3}$. \\ 1,2,3. Departemen Teknik Mesin, Politeknik Negeri Indramayu, Jl. Lohbener Lama no. 8 Lohbener Indramayu \\ Jawa Barat, 45252 . \\ E-mail : '1delffika.canra@polindra.ac.id, ${ }^{2}$ eminharis@gmail.com, ${ }^{3}$ meri@polindra.ac.id.
}

\begin{abstract}
Abstrak
Sumber energi angin didaerah pesisir Indonesia umumnya merupakan salah satu potensi sumber energi terbarukan (renewable energy resources) yang berlimpah, ramah lingkungan dan bersifat renewable. Turbin angin savonius dapat menghasilkan torsi yang relatif tinggi meskipun pada kecepatan angin rendah. Karena itu sangat baik sekali dikembangkan untuk menghasilkan energi listrik. Untuk mendapatkan daya listrik yang besar diperlukan konstruksi turbin yang besar juga dimana memerlukan biaya yang besar juga tentunya. Untuk itu perlu dikembagkan dimensi dari konstruksi turbin angin ini yang dikenal dengan aspect ratio(Ar). Ar yang sudah diteliti adalah penampang sudu, serta nilai lainnya. Sedangkan kedalaman lengkungan atau panjang busur sudu pada tipe U masih berpeluang diteliti. Oleh karena itu perlu dilakukan penelitian pada busur sudu tipe U untuk mendapatkan daya yang lebih besar dari sebelumnya. Selain Metode experimental dengan mebuat prototipe turbin angin savonius tipe $U$ dengan jumlah sudu 2 buah, metode simulasi berbasis software akan dilakukan untuk analisa aliran udara pada sudu turbin angin tersebut. Parameter yang divariasikan hanya pada aspect ratio panjang busur dan lebar penampang sudu, parameter lainnya mengikuti penelitian sebelumnya. Analisa ini akan menjadi data pembanding dengan metode experimental. Hasil simulasi yang diharapkan mendapatkan aspect ratio(Ar) sudu terbaik dalam menangkap energi angin.
\end{abstract}

Keyword :Turbin angin, savonius, Tipe $U$, aspect ratio, panjang busur sudu

\begin{abstract}
Generally, wind energy sources in Indonesia's coastal areas is one of the potential sources of renewable energy (renewable energy resources) which are abundant, environmentally friendly and renewable. Savonius wind turbines can produce relatively high torque even at low wind speeds. Because it is very well developed to produce electrical energy. To get a large electric power, a large turbine construction is also needed which also certainly requires a large cost. For this reason, it is necessary to develop the dimensions of this wind turbine construction which is known as aspect ratio (Ar). The Ar that has been researched is the blade section, and other values. While the arch depth or the length of the blade arc in $U$-type is still likely to be researched. Therefore, it is necessary to do research on the $U$-type blade arc to get greater power than before. In addition to the experimental method with a prototype of the U type Savonius wind turbine with a number of 2 blades, a softwarebased simulation method will be carried out to analyze the air flow on the wind turbine blade. Parameters varied only with the aspect ratio of the arc length and blade cross section width, other parameters follow the previous research. This analysis will be a comparative data with experimental methods. The expected simulation results obtain the best aspect ratio (Ar) blade in capturing wind energy.
\end{abstract}

Keyword :Wind Turbine, savonius, $U$-type, aspect ratio, panjang busur sudu, arc length of blade

\section{PENDAhuluan}

Sumber energi angin didaerah pesisir Indonesia umumnya merupakan salah satu potensi sumber energi terbarukan (renewable energy resources) yang berlimpah, ramah lingkungan dan bersifat renewable. Kecepatan angin di Indonesia secara umum rata-rata $3-7 \mathrm{~m} / \mathrm{s}$ yang tergolong kecepatan angin rendah.
Untuk memanfaatakan potensi angin ini, turbin yang terbaik digunakan adalah turbin angin savonius karena dapat berputar pada kecepatan angin rendah. Kelebihan turbin angin savonius dapat menghasilkan torsi yang relatif tinggi meskipun pada kecepatan angin rendah. Karena itu sangat baik sekali dikembangkan untuk menghasilkan energi listrik. 
Banyak sekali penelitian yang sudah dilakukan untuk mengembangkan konstruksi turbin angin ini dan terus dikembangkan untuk menghasilkan daya listrik yang optimal. Pengembangan konstruksi yang sudah dilakukan adalah memvariasikan bentuk sudu, jumlah sudu, sudut sudu, tingkat sudu (multi stage), penahan (shield) dan pengarah (deflector), sehingga banyak sekali jenis sudu yang ada pada turbin ini mulai dari tipe U (bucket) yang merupakan tipe sudu awal ditemukan atau konvensional, tipe L, sudu miring (twisted-blade), sudu bertingkat dan lainnya.

Untuk mendapatkan daya listrik yang besar diperlukan konstruksi turbin yang besar juga dimana memerlukan biaya yang besar juga tentunya. Untuk itu perlu dikembagkan dimensi dari konstruksi turbin angin ini yang dikenal dengan aspect ratio(Ar). Ar yang sudah diteliti adalah penampang sudu, serta nilai parameter lainnya. Sedangkan kedalaman lengkungan atau panjang busur sudu pada tipe $U$ masih berpeluang diteliti. Oleh karena itu perlu dilakukan penelitian pada busur sudu tipe $U$ untuk mendapatkan daya yang lebih besar dari sebelumnya.

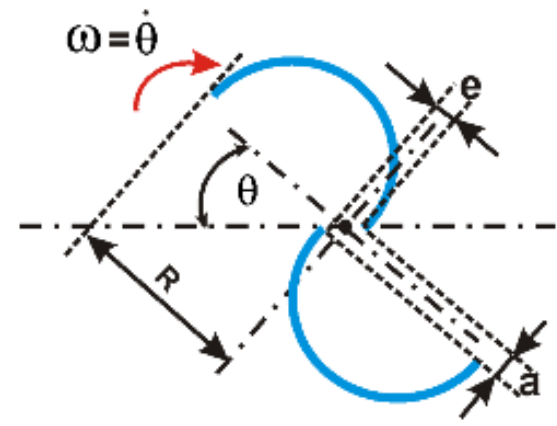

Gambar 1. Skema nilai parameter geomatrikal sudu turbin savonius

Penelitan yang dilakukan oleh Mohamed Hasan A. M dalam desertasinya pada tahun 2011 dengan judul "Design Optimazation of Savonius and Wells Turbines", mengungkapkan bahwa ada beberapa metoda untuk meningkatkan performa dari turbin angin savonius tipe U (conventional savonius rotors). Pertama adalah menempatkan deflecting plate didepan sudu turbin. Hal ini meningkatkan Cp (Coefficient of Power) sebesar $20 \%$. Metoda kedua yakni multi steps atau sudu bertingkat. Sudu ini dapat bergerak awal dengan baik (good self-starting) akan tetapi mengalami penurunan Cp sebesar $30 \%$. Ketiga yakni Guide vanes dimana Cp yang dihasilkan 3 sudu lebih kecil dibandingkan 2 sudu. Metoda ini meningkatkan torsi pada TSR (Tip Ratio Speed) 0 hingga 0,3 akan tetapi menurunkan torsi apabila TSR melebihi dari 0,3. Oleh karena itu sudu ini tergantung sekali dengan kecepatan angin. Metoda yang keempat adalah twisted-blade (sudu miring), Cp yang dihasilkan meningkat 27\%, sedangkan kelemahan dari sudu ini adalah butuh biaya mahal dalam pembuatan sudu. Kelima, sudu turbin menggunakan guide-box tunnel sebagai penahan (deflector) angin untuk mencegah sudu berbalik (returning blade). Cp meningkat $50 \%$ pada 3 sudu, kelemahannya hanya pada konstruksi yang kompleks. Yang keenam adalah memodifikasi sudu dengan cara memberikan nilai parameter geometrikal yakni nilai overlap dan sudut antara sudu (lihat Gbr.1). Hal ini meningkatkan Cp sebesar $60 \%$, dan menghasilkan vibrasi yang besar. Metode yang keenam selalu digunakan dalam mendesain sudu turbin karena sudah terbukti meningkatkan Cp lebih signifikan dari desain sudu konvensional.

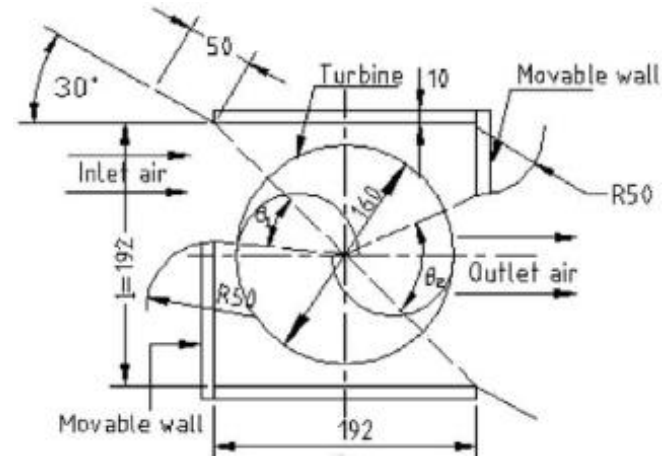

(a)

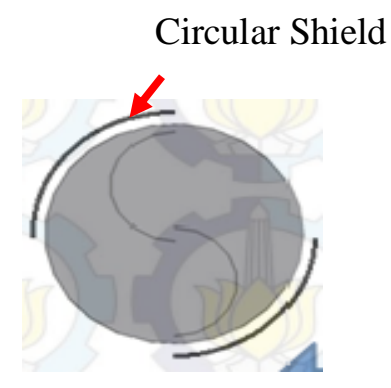

(b)

Gambar 2. Skema turbin angin menggunakan (a) Guide-box tunnel (b) Circular Shield

M. Haydarul H. dkk pada tahun 2013 dengan judul penelitian "Rancang Bangun Turbin Angin Vertikal Jenis Savonius dengan Variasi Jumlah Blade Terintegrasi Circular Shield untuk Memperoleh Daya Maksimum", mendapatkan nilai Cp yang signifikan yakni rata-rata $80 \%$ dibandingkan dengan sudu savonius tipe $U$ konvensional. Peneliti ini menggunakan metode yang kelima yakni menggunakan guide-box tunnel (kotak laluan angin), hanya saja dimodifikasi berbentuk silinder (Circular Shield). Nilai parameter geometrikal yang dipakai adalah nilai overlap sebesar $20 \%$ dari diameter endplate. Kemudian aspek rasio sudu adalah $1: 4$. Pada penelitian ini juga membuktikan bahwa peforma sudu yang terbaik adalah pada saat jumlah sudu sebanyak 2 dibandingkan dengan jumlah sudu yang lebih dari 2. Hal ini diasumsikan oleh peneliti dikarenakan beban material mempengaruhi putaran sudu. 


\section{METODE}

1. Desain Turbin

Dimensi sampel awal didesain seperti yang terlihat pada gambar 3 yakni lebar penampang sudu adalah $100 \mathrm{~mm}$, diameter endplate $200 \mathrm{~mm}$, celah untuk overlap ratio adalah $20 \mathrm{~mm}$ dan $10 \mathrm{~mm}$, dan radius sudu awal adalah $50 \mathrm{~mm}$.

Percobaan akan dilakukan dengan memvariasikan panjang busur yakni dengan memvariasikan besar radius sudu sedangkan lebar penampang sudu konstan. Variasi radius yang direncanakan adalah radius 60 - $80 \mathrm{~mm}$ dengan resolusi $5 \mathrm{~mm}$.

Kemudian percobaan dilanjutkan dengan memvariasikan lebar penampang sudu sedangkan panjang busur konstan yakni $157 \mathrm{~mm}$. Variasi lebar penampang sudu yang direncanakan adalah 80 - 130 $\mathrm{mm}$ dengan resolusi $10 \mathrm{~mm}$, sedangkan ukuran endplate menyesuaikan dengan lebar penampang sudu. Dimensi lainnya konstan.

Kecepatan angin yang digunakan pada simulasi adalah 3,6 sampai $4,8 \mathrm{~m} / \mathrm{s}$ dengan resolusi $0,4 \mathrm{~m} / \mathrm{s}$, sesuai dengan penelitian sebelumnya.

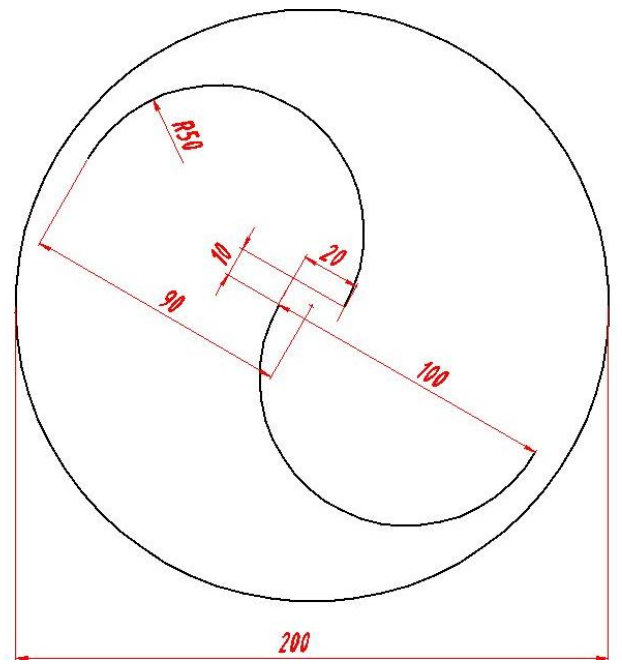

Gambar 3. Dimensi sudu turbin angin awal.

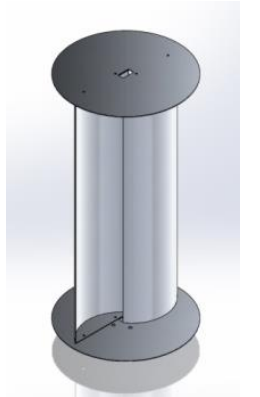

Gambar 4. Model sudu turbin.

2. Prosedur simulasi.

Simulasi dilakukan menggunakan software SolidWork yang memiliki fitur simulasi. Sebelumnya dibuatkan modeling sudu turbin seperti pada gambar 4 , sebanyak variasi yang akan disimulasikan.
Kemudian dibuatkan wind tunnel simulation untuk batasan angin menimpa sudu turbin seperti pada gambar 5.

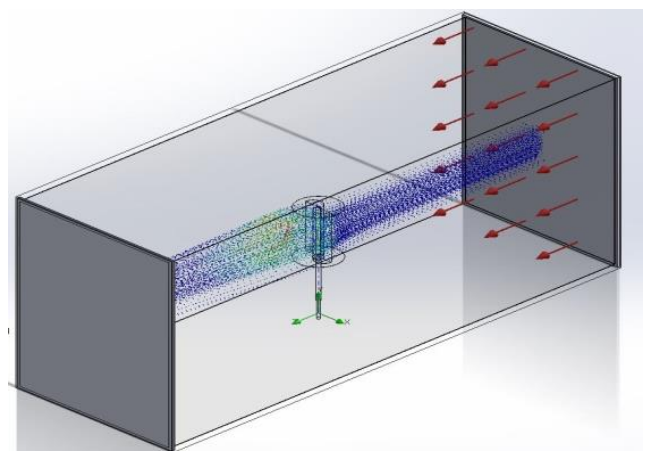

Gambar 5. Simulasi Aliran Angin

Variasi simulasi lanjutannya adalah menambahkan circular shield didepan sudu seperti pada gambar 6 .

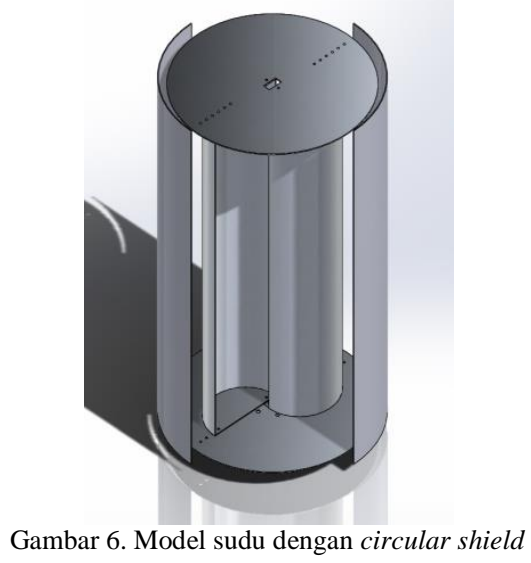

\section{Teori Dasar}

Turbin angin savonius ditemukan pada tahun 1920 oleh SJ Savonius dengan prinsip bentuk sudu pada awalnya adalah plat tabung dibelah dua dan disatukan bersilang hingga menyerupai huruf S. Turbin angin Savonius ini dikenal dengan turbin angin savonius konvensional (Tipe U bucket).

Dengan menggunakan teori momentum Betz dimana angin kecepatan $\mathrm{v}_{1}$ melewati sebuah sudu turbin angin mengalami perubahan kecepatan $\mathrm{v}_{2}$, sehingga daya turbin yang bekerja dapat diformulasikan :

$$
P=\frac{1}{4} \rho A\left(v_{1}+v_{2}\right) \cdot\left(v_{1}^{2}-v_{2}^{2}\right)
$$

dimana $\mathrm{P}$ adalah daya turbin, $\rho$ merupakan kerapatan udara, A adalah luas sapuan,dan $\mathrm{v}$ adalah kecepatan angin.

Koefisien daya atau Coefficient of power (Cp) menentukan performa dari turbin angin tersebut dimana energi angin menentukan besarnya energi kinetik angin yang melalui sudu turbin angin tersebut dan dapat diformulasikan :

$$
P_{0}=\frac{1}{2} \rho A v_{1}^{3}
$$


dimana $\mathrm{P}_{0}$ adalah daya angin. Sehingga Koefisien daya turbin dapat diformulasikan :

$$
C p=\frac{P}{P_{0}}=\frac{\frac{1}{4} \rho A\left(v_{1}+v_{2}\right) \cdot\left(v_{1}^{2}-v_{2}^{2}\right)}{\frac{1}{2} \rho A v_{1}^{3}}
$$

Menghitung besar torsi yang terjadi juga tidak kalah pentingnya. Torsi bisa didefinisikan ukuran keefekrifan gaya tersebut dalam menghasilkan putaran atau rotasi mengelilingi sumbu tersebut. Besarnya torsi dapat diformulasikan :

$$
T=\frac{v^{2} r^{3}}{\lambda^{2}}
$$

dimana $\mathrm{T}$ adalah Torsi, $\mathrm{v}$ merupakan kecepatan angin, $\mathrm{r}$ adalah lebar penampang sudu, dan $\lambda$ adalah tip ratio speed. Sedangkan tip ratio speed dihitung dengan formula :

$$
\lambda=\frac{\pi D n}{60 v}
$$

dimana $\mathrm{D}$ merupakan diameter sudau, $n$ adalah putaran poros/sudu dan $v$ merupakan kecepatan angin.

\section{HASIL DAN PEMBAHASAN}

1. Simulasi Turbulence, torsi, dan kecepatan angin tanpa circular shield (CS).

Simulasi ini dilakukan untuk melihat seberapa besar turbulence, torsi dan selisih kecepatan angin masuk dan keluar dari sudu yang terjadi, seperti gambar 7 .

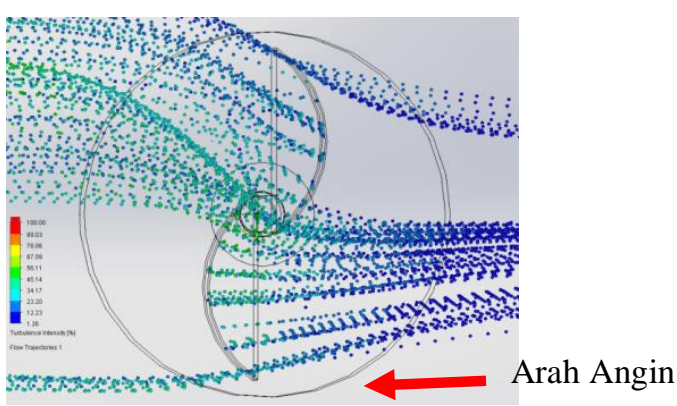

(a)

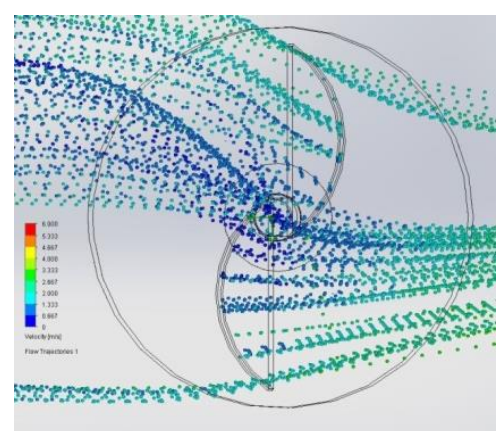

(b)

Gambar 7. Simulasi (a) turbulence (b) kecepatan angin variasi radius tanpa $\mathrm{CS}$.

\section{Perbandingan Kecepatan angin dengan} Turbulence
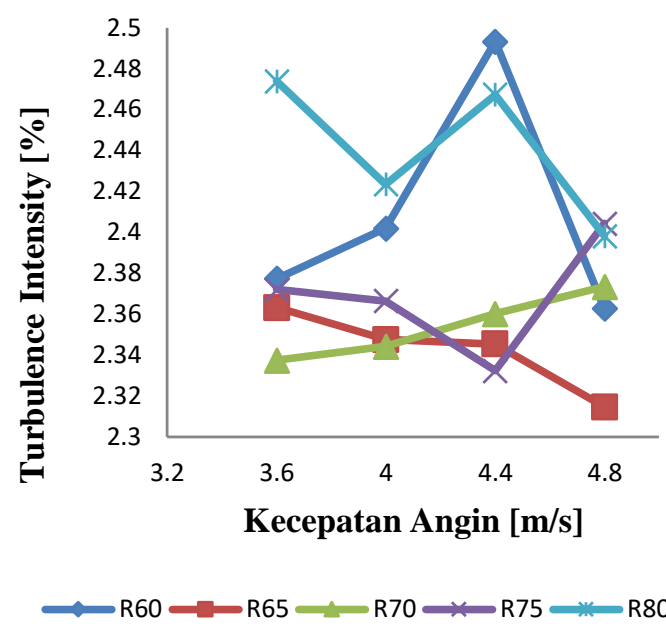

\begin{tabular}{|c|c|c|c|c|}
\hline No & $\begin{array}{c}\text { Radi } \\
\text { us }\end{array}$ & $\begin{array}{c}\text { Kecepatan } \\
\text { Angin } \\
\text { masuk } \\
\text { (V1) }[\mathrm{m} / \mathrm{s}]\end{array}$ & $\begin{array}{c}\text { Kecepatan } \\
\text { Angin } \\
\text { keluar } \\
\text { (V2) }[\mathrm{m} / \mathrm{s}]\end{array}$ & $\begin{array}{l}\mathrm{V} 1-\mathrm{V} 2 \\
{[\mathrm{~m} / \mathrm{s}]}\end{array}$ \\
\hline \multirow{4}{*}{1} & \multirow{4}{*}{ R60 } & 3,6 & 2 & 1,6 \\
\hline & & 4 & 2,2 & 1,8 \\
\hline & & 4,4 & 1,3 & 3,1 \\
\hline & & 4,8 & 2,6 & 2,2 \\
\hline \multirow{4}{*}{2} & \multirow{4}{*}{$\mathrm{R} 65$} & 3,6 & 2 & 1,6 \\
\hline & & 4 & 2,3 & 1,7 \\
\hline & & 4,4 & 2 & 2,4 \\
\hline & & 4,8 & 2,6 & 2,2 \\
\hline \multirow{4}{*}{3} & \multirow{4}{*}{$\mathrm{R} 70$} & 3,6 & 2 & 1,6 \\
\hline & & 4 & 2 & 2 \\
\hline & & 4,4 & 3 & 1,4 \\
\hline & & 4,8 & 3,3 & 1,5 \\
\hline \multirow{4}{*}{4} & \multirow{4}{*}{$\mathrm{R} 75$} & 3,6 & 1,3 & 2,3 \\
\hline & & 4 & 2 & 2 \\
\hline & & 4,4 & 1,3 & 3,1 \\
\hline & & 4,8 & 2,4 & 2,4 \\
\hline \multirow{4}{*}{5} & \multirow{4}{*}{$\mathrm{R} 80$} & 3,6 & 2,5 & 1,1 \\
\hline & & 4 & 2,3 & 1,7 \\
\hline & & 4,4 & 3 & 1,4 \\
\hline & & 4,8 & 2,5 & 2,3 \\
\hline
\end{tabular}

Gambar 8. Grafik simulasi turbulence variasi radius tanpa CS

Tabel 1. Hasil Simulasi Kecepatan Angin variasi radius tanpa CS

Berdasarkan grafik gambar 8, dapat dilihat bahwasanya turbulence semakin kecil dan kecepatan semakin meningkat terjadi pada variasi sudu berradius 65 , bertolak belakang dengan sudu $\mathrm{R} 70$ dan yang lainnya menunjukkan grafik yang tidak stabil. varisi sudu disini memiliki lebar penampang yang konstan yakni $100 \mathrm{~mm}$.

Kemudian hasil simulasi kecepatan angin memperlihatkan bahwa selisih kecepatangan angin masuk $\left(v_{1}\right)$ dengan kecepatan keluar $\left(v_{2}\right)$ yang terbesar ditunjukkan oleh sudu R60 dan R75 pada kecepatan angin $4,4 \mathrm{~m} / \mathrm{s}$. 
Sedangkan torsi yang terjadi pada simulasi menunjukkan variasi sudu R60 dan R65 memiliki angka yang besar, akan tetapi melihat dari tren garis grafik pada gambar 9, R65 menunjukkan peningkatan yang stabil.

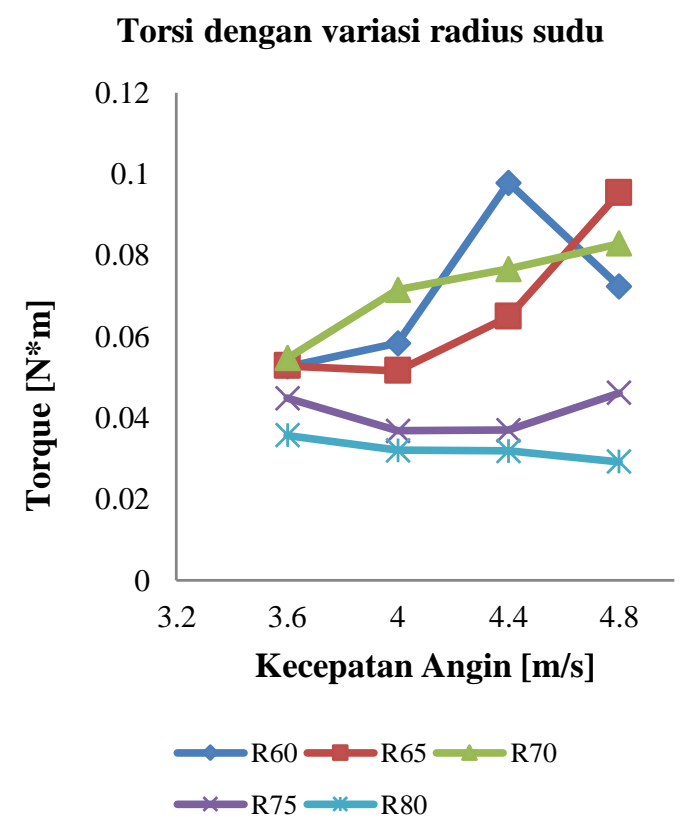

Gambar 9. Grafik simulasi torsi variasi radius tanpa CS

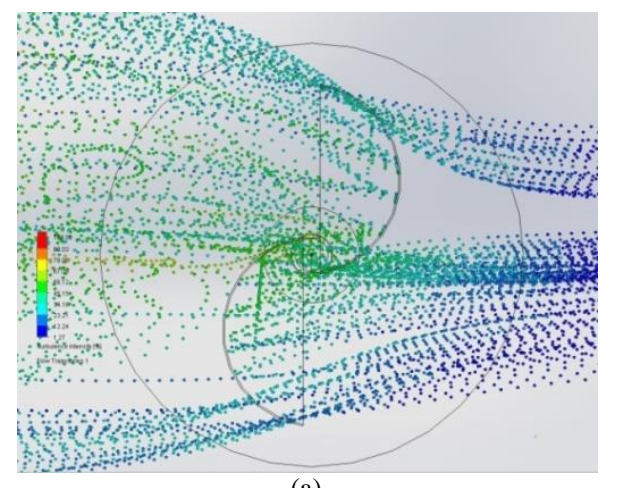

(a)

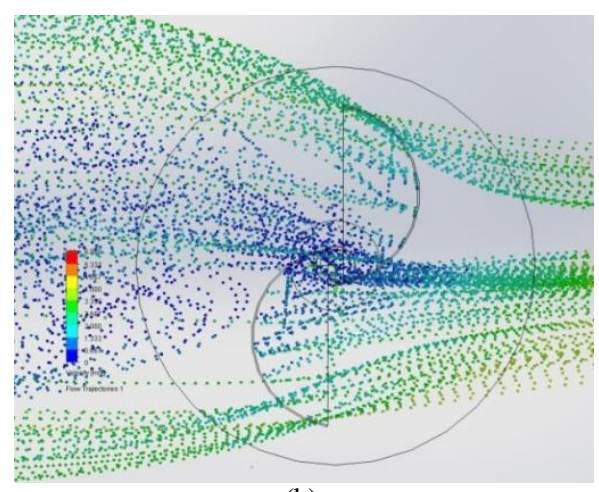

(b)

Gambar 10. Simulasi (a) turbulence (b) kecepatan angin variasi lebar penampang tanpa CS

\section{Turbulence variasi lebar penampang}

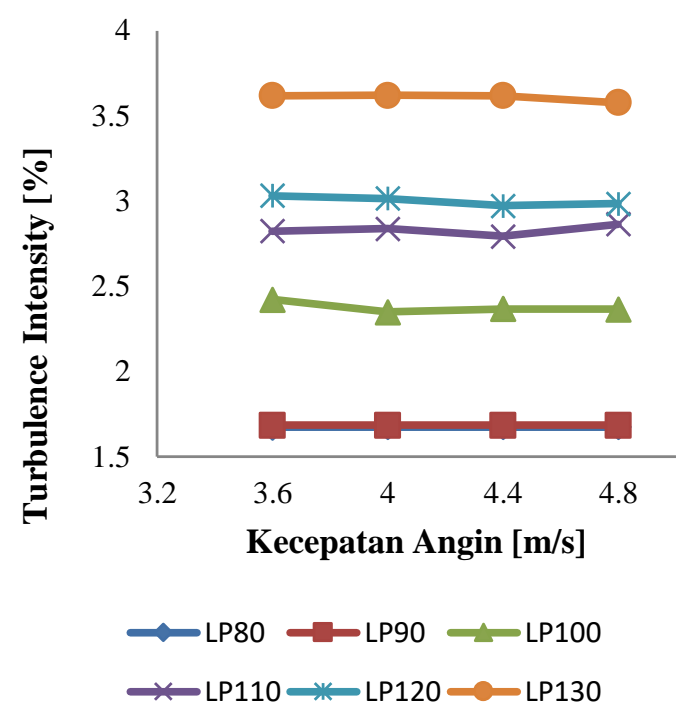

Gambar 11. Grafik simulasi turbulence variasi lebar penampang tanpa CS

Tabel 2. Hasil Simulasi Kecepatan Angin variasi lebar penampang tanpa CS

\begin{tabular}{|c|c|c|c|c|}
\hline $\begin{array}{l}\mathrm{N} \\
\mathrm{O}\end{array}$ & $\begin{array}{l}\text { Lebar } \\
\text { Penam } \\
\text { pang }\end{array}$ & $\begin{array}{c}\text { Kecepatan } \\
\text { Angin } \\
\text { masuk } \\
\mathrm{V} 1[\mathrm{~m} / \mathrm{s}]\end{array}$ & $\begin{array}{c}\text { Kecepatan } \\
\text { Angin } \\
\text { masuk } \\
\text { V2[m/s] }\end{array}$ & $\begin{array}{l}\mathrm{V} 1-\mathrm{V} 2 \\
{[\mathrm{~m} / \mathrm{s}]}\end{array}$ \\
\hline \multirow{4}{*}{1} & \multirow{4}{*}{ LP80 } & 3,6 & 2,6 & 1 \\
\hline & & 4 & 3 & 1 \\
\hline & & 4,4 & 3,3 & 1,1 \\
\hline & & 4,8 & 4 & 0,8 \\
\hline \multirow{4}{*}{2} & \multirow{4}{*}{ LP90 } & 3,6 & 2,3 & 1,3 \\
\hline & & 4 & 3 & 1 \\
\hline & & 4,4 & 3 & 1,4 \\
\hline & & 4,8 & 4 & 0,8 \\
\hline \multirow{4}{*}{3} & \multirow{4}{*}{ LP100 } & 3,6 & 1,3 & 2,3 \\
\hline & & 4 & 1,3 & 2,7 \\
\hline & & 4,4 & 2 & 2,4 \\
\hline & & 4,8 & 1,3 & 3,5 \\
\hline \multirow{4}{*}{4} & \multirow{4}{*}{ LP110 } & 3,6 & 2 & 1,6 \\
\hline & & 4 & 2 & 2 \\
\hline & & 4,4 & 2 & 2,4 \\
\hline & & 4,8 & 2,5 & 2,3 \\
\hline \multirow{4}{*}{5} & \multirow{4}{*}{ LP120 } & 3,6 & 1,3 & 2,3 \\
\hline & & 4 & 2 & 2 \\
\hline & & 4,4 & 2 & 2,4 \\
\hline & & 4,8 & 2,2 & 2,6 \\
\hline \multirow{4}{*}{6} & \multirow{4}{*}{ LP130 } & 3,6 & 1,3 & 2,3 \\
\hline & & 4 & 2 & 2 \\
\hline & & 4,4 & 2 & 2,4 \\
\hline & & 4,8 & 2 & 2,8 \\
\hline
\end{tabular}




\section{Torsi variasi lebar penampang}
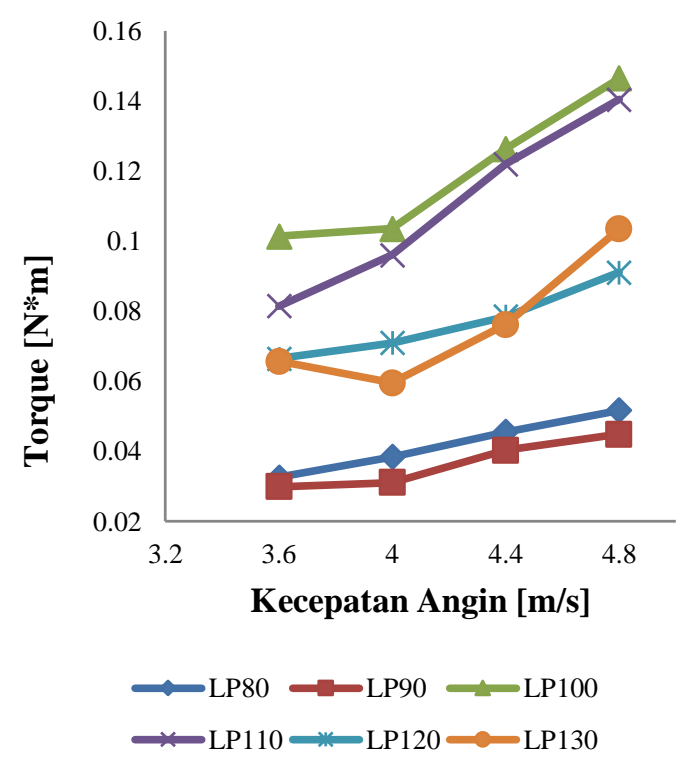

Gambar 12. Grafik simulasi torsi variasi lebar penampang tanpa CS

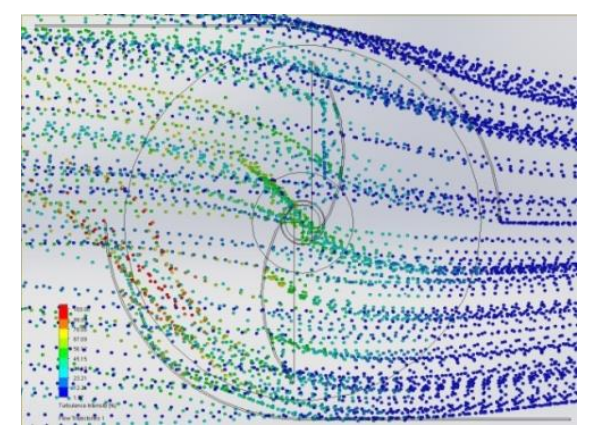

(a)

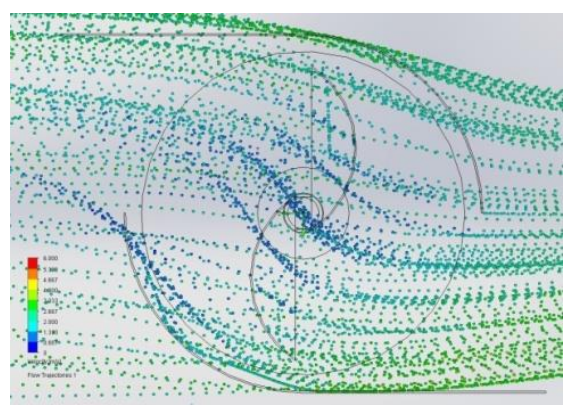

(b)

Gambar 13. Simulasi (a) turbulence (b) kecepatan angin variasi radius dengan $\mathrm{CS}$.

Variasi kedua yakni varian lebar penampang dengan panjang busur konstan yakni $157 \mathrm{~mm}$, hasil simulasi dapat dilihat pada gambar 10,11 dan 12 serta tabel 2 . Turbulence yang terjadi pada setiap sudu cendrung stabil pada setiap peningkatan kecepatan angin. Luas penampang ternyata mempengaruhi besar atau banyaknya turbulence terjadi di penampang sudu, semakin luas maka semakin besar turbulance yang terjadi. Dari grafik dapat dilihat bahwa LP 80 dan LP 90 memiliki turbulence yang kecil, akan tetapi pada tabel selisih kecepatan dan grafik torsi menunjukkan bahwa LP80 dan LP90 memiliki angka yang kecil. Untuk selisih kecepatan yang terbaik adalah variasi LP 100 pada kecepatangan angin 4,8 serta di ikuti dengan besarnya torsi yang dihasilkan dibandingkan dengan variasi lainnya.

2. Simulasi Turbulence, torsi, dan kecepatan angin menggunakan circular shield.

\section{Turbulence variasi radius}
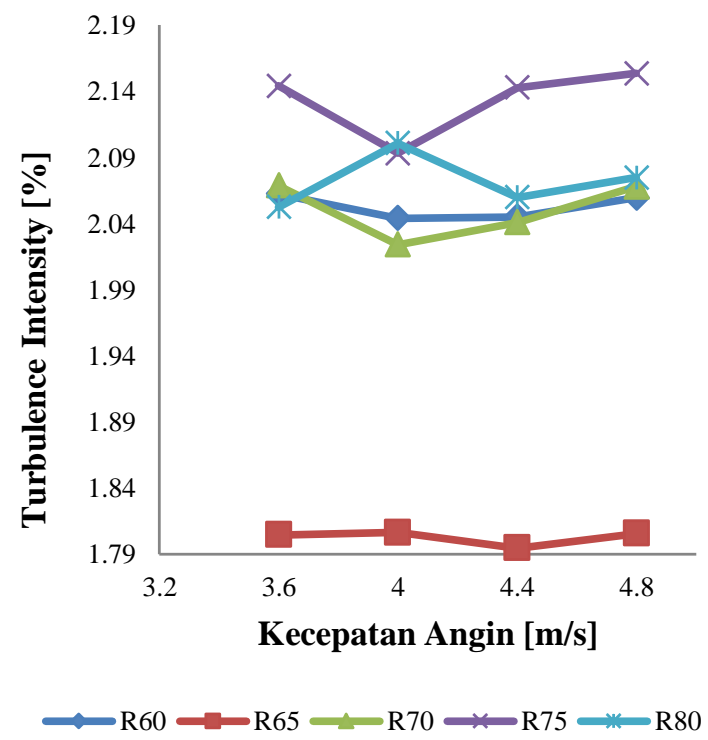

Gambar 14. Grafik simulasi turbulence variasi radius dengan CS

Tabel 3. Hasil Simulasi Kecepatan Angin variasi radius dengan

\begin{tabular}{|c|c|c|c|c|}
\hline No & Radius & $\begin{array}{c}\text { Kecepatan } \\
\text { Angin V1 } \\
{[\mathrm{m} / \mathrm{s}]}\end{array}$ & $\begin{array}{c}\text { Kecepatan } \\
\text { Angin V2 } \\
{[\mathrm{m} / \mathrm{s}]}\end{array}$ & $\begin{array}{c}\mathrm{V} 1-\mathrm{V} 2 \\
{[\mathrm{~m} / \mathrm{s}]}\end{array}$ \\
\hline \multirow{4}{*}{1} & \multirow{4}{*}{ R60 } & 3,6 & 2 & 1,6 \\
\hline & & 4 & 2,6 & 1,4 \\
\hline & & 4,4 & 3 & 1,4 \\
\hline & & 4,8 & 3,3 & 1,5 \\
\hline \multirow{4}{*}{2} & \multirow{4}{*}{ R65 } & 3,6 & 2,6 & 1 \\
\hline & & 4 & 2,6 & 1,4 \\
\hline & & 4,4 & 3,3 & 1,1 \\
\hline & & 4,8 & 3,3 & 1,5 \\
\hline \multirow{4}{*}{3} & \multirow{4}{*}{ R70 } & 3,6 & 2 & 1,6 \\
\hline & & 4 & 2 & 2 \\
\hline & & 4,4 & 2,3 & 2,1 \\
\hline & & 4,8 & 2,3 & 2,5 \\
\hline \multirow{4}{*}{4} & \multirow{4}{*}{ R75 } & 3,6 & 2,3 & 1,3 \\
\hline & & 4 & 2,3 & 1,7 \\
\hline & & 4,4 & 2,6 & 1,8 \\
\hline & & 4,8 & 2,6 & 2,2 \\
\hline \multirow{4}{*}{5} & \multirow{4}{*}{ R80 } & 3,6 & 2,6 & 1 \\
\hline & & 4 & 2,6 & 1,4 \\
\hline & & 4,4 & 3 & 1,4 \\
\hline & & 4,8 & 3 & 1,8 \\
\hline
\end{tabular}




\section{Torsi variasi radius}

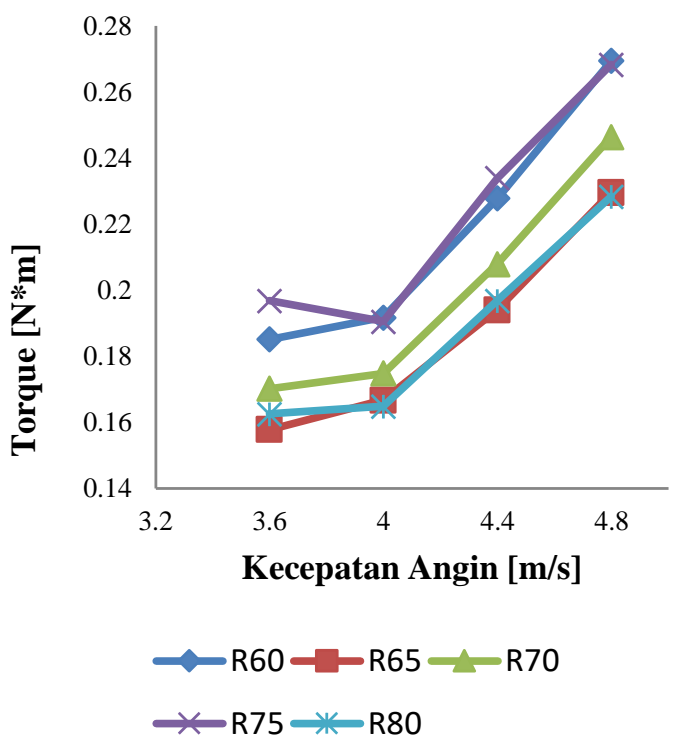

Gambar 15. Grafik simulasi torsi variasi radius dengan CS

Simulasi yang sama dilakukan akan tetapi setengah diameter sudu ditutup menggunakan circular shield (gambar 13) sesuai dengan penelitian sebelumnya bahwasanya dapat meningkatkan power hingga $50 \%$. Turbulence terkecil terdapat pada sudu R65 dan terbesar terjadi pada sudu R75 dan tren dari grafik cendrung stabil seperti pada gambar 14 .

Semua torsi naik seiring dengan naiknya kecepatan angin dan yang terbaik adalah sudu R60 dan R75 saat kecepatan angin $4,8 \mathrm{~m} / \mathrm{s}$ yang diperlihatkan gambar 15. Sedangkan pada tabel 3 , selisih terbesar $2,5 \mathrm{~m} / \mathrm{s}$ dari kecepatan angin $v_{1}$ dan $v_{2}$ terdapat pada sudu R70 pada kecepatan angin $4,8 \mathrm{~m} / \mathrm{s}$.

Kemudian dilanjutkan dengan variasi kedua yakni panjang busur yang konstan sebesar $157 \mathrm{~mm}$. Gambar 16 menunjukan hasil simulasi turbulence dan kecepatan angin. Turbulence terkecil terjadi pada LP 80 dan LP 90 dan stabil di semua peningkatan kecepatan angin seperti diperlihatkan pada gambar 17. Sedangkan pada LP100 menunjukkan penurunan setelah kecepatan angin naik diatas $4 \mathrm{~m} / \mathrm{s}$. LP 130 juga menunjukkan turbulence yang stabil hanya saja meningkat seiring dengan meningkatnya kecepatan angin. LP 110 dan LP 120 memperlihatkan ketidak stabilan turbulence yang terjadi setiap peningkatan kecepatan angin.

Berdasarkan tabel 4, menunjukkan bahwa selisih terbesar dari kecepatan angin masuk dan keluar adalah pada LP 100 dan LP 120 saat kecepatan angin diatas $4 \mathrm{~m} / \mathrm{s}$. Apabila diperhatikan lebih lanjut bahwa LP 100, LP 110 dan LP 120 memperlihatkan kestabilan selisih kecepatan angin masuk dan keluar, hal ini sangat mempengaruhi daya angin terhadap sudu turbin.

Torsi terbesar terjadi pada LP 100 dan LP 130 seperti diperlihatkan pada gambar 18, dan kecendrungan stabil naik seiring dengan kecepatan angin. Sedangkan torsi terendah ditunjukkan oleh LP 80 . Berbeda dengan LP 90, LP 110 dan LP 120 menjadi torsi menengah antara yang tertinggi dan terendah yang kecendrungan stabil naik seiring dengan kecepatan angin.

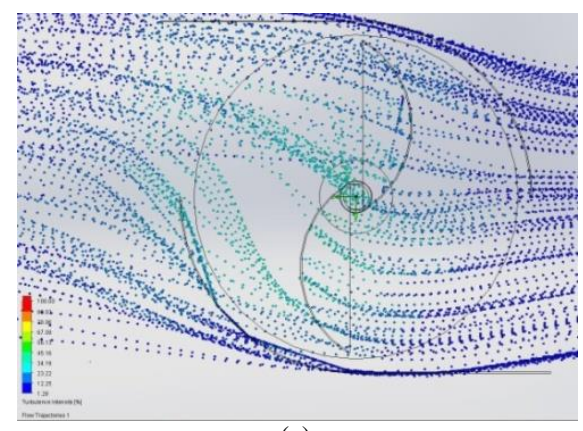

(a)

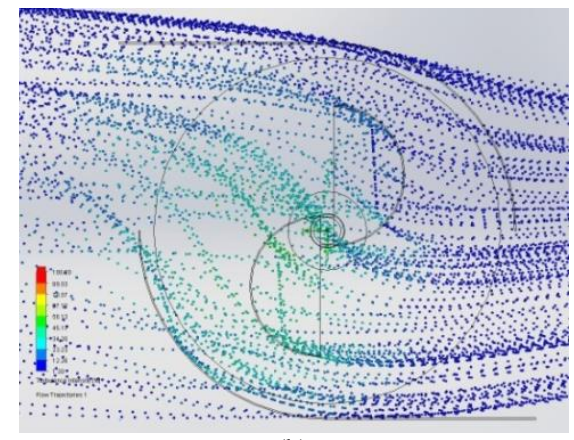

(b)

Gambar 16. Simulasi (a) turbulence (b) kecepatan angin variasi lebar penampang dengan CS

\section{Turbulence variasi lebar penampang}

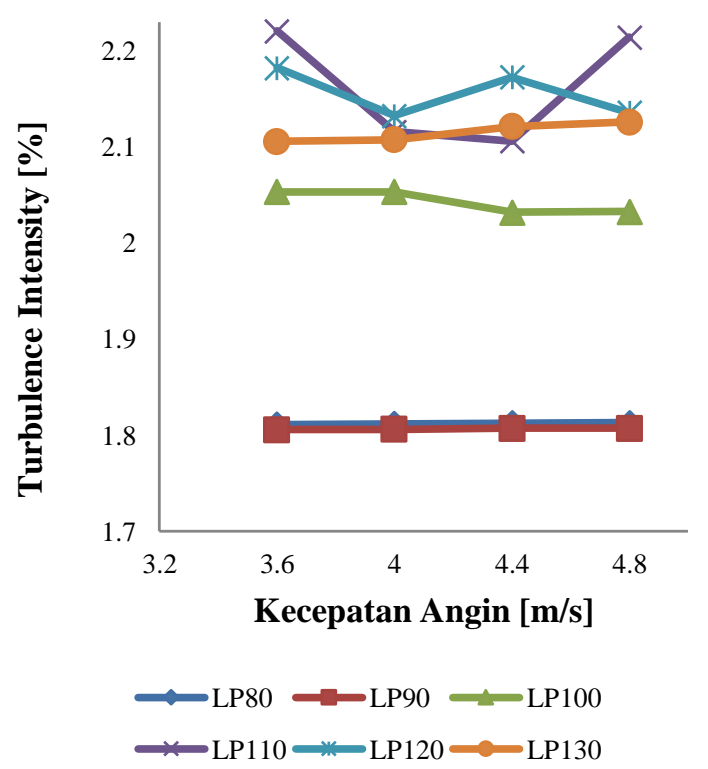

Gambar 17. Grafik simulasi turbulence variasi lebar penampang dengan CS

Tabel 4. Hasil Simulasi Kecepatan Angin variasi lebar penampang dengan $\mathrm{CS}$ 


\begin{tabular}{|c|c|c|c|c|}
\hline $\begin{array}{c}\mathrm{N} \\
\mathrm{O}\end{array}$ & $\begin{array}{c}\text { Lebar } \\
\text { Penam- } \\
\text { pang }\end{array}$ & $\begin{array}{c}\text { Kecepatan } \\
\text { Angin V1 } \\
{[\mathrm{m} / \mathrm{s}]}\end{array}$ & $\begin{array}{c}\text { Kecepatan } \\
\text { Angin V2 } \\
{[\mathrm{m} / \mathrm{s}]}\end{array}$ & $\begin{array}{c}\mathrm{V} 1- \\
\mathrm{V} 2 \\
{[\mathrm{~m} / \mathrm{s}]} \\
\end{array}$ \\
\hline \multirow{4}{*}{1} & \multirow{4}{*}{ LP80 } & 3,6 & 2,6 & 1 \\
\hline & & 4 & 2,6 & 1,4 \\
\hline & & 4,4 & 2,6 & 1,8 \\
\hline & & 4,8 & 3,3 & 1,5 \\
\hline \multirow{4}{*}{2} & \multirow{4}{*}{ LP90 } & 3,6 & 2,6 & 1 \\
\hline & & 4 & 2,6 & 1,4 \\
\hline & & 4,4 & 3 & 1,4 \\
\hline & & 4,8 & 3,3 & 1,5 \\
\hline \multirow{4}{*}{3} & \multirow{4}{*}{ LP100 } & 3,6 & 2 & 1,6 \\
\hline & & 4 & 1,3 & 2,7 \\
\hline & & 4,4 & 2 & 2,4 \\
\hline & & 4,8 & 2 & 2,8 \\
\hline \multirow{4}{*}{4} & \multirow{4}{*}{ LP110 } & 3,6 & 1,6 & 2 \\
\hline & & 4 & 1,6 & 2,4 \\
\hline & & 4,4 & 2 & 2,4 \\
\hline & & 4,8 & 2 & 2,8 \\
\hline \multirow{4}{*}{5} & \multirow{4}{*}{ LP120 } & 3,6 & 1,3 & 2,3 \\
\hline & & 4 & 1,3 & 2,7 \\
\hline & & 4,4 & 1,6 & 2,8 \\
\hline & & 4,8 & 2 & 2,8 \\
\hline \multirow{4}{*}{6} & \multirow{4}{*}{ LP130 } & 3,6 & 1,3 & 2,3 \\
\hline & & 4 & 1,6 & 2,4 \\
\hline & & 4,4 & 2 & 2,4 \\
\hline & & 4,8 & 2,6 & 2,2 \\
\hline
\end{tabular}

\section{PENUTUP}

\section{Kesimpulan}

Dari hasil penelitian disimpulkan bahwa dimensi dari sudu baik itu radius maupun lebar penampang sangat mempengaruhi aliran udara yang melewati sudu turbin. Simulasi tanpa menggunakan circular sheild memperlihatkan bahwa sudu yang beradius $65 \mathrm{~mm}$ dan lebar penampang $100 \mathrm{~mm}$ merupakan variasi terbaik berdasarkan dari tiga parameter simulasi aliran udara tersebut.

Simulasi menggunakan circular sheild menunjukkan bahwa sudu dan lebar penampang terbaik adalah $\mathrm{R}$ 75 dan LP 100.

\section{Saran}

Sebaiknya simulasi tidak hanya menggunakan 1 jenis Software saja agar supaya data yang didapatkan bisa saling dibandingkan. Selain itu variasi kecepatan anginnya sebaiknya diperbanyak.

\section{DAFTAR PUSTAKA}

Rudianto D.T, Ahmadi N. 2016. Rancang Bangun Turbin Angin Savonius 200 Watt. Seminar Nasional Teknologi Informasi dan Kedirgantaraan (SENATIK). Vol : 2. Hal : 7175. Yogyakarta.

Farid. A. 2014. Optimasi Daya Turbin Angin Savonius dengan Variasi Celah dan Perubahan Jumlah Sudu. Prosiding SNST ke-5 Fakultas Teknik Universitas Wahid Hasyim. Vol : 5. Hal : 18-23. Semarang.

M. Haydarul. H, Nugroho. G, Musyafa'.A. 2013. Rancang Bangun Turbin Angin Vertikal Jenis Savonius dengan Variasi Jumlah Blade Terintegrasi Circular Shield untuk Memperoleh daya Maksimum. Jurnal Teknik POMITS.; Vol : 7. Hal : 1-6. Bandung.

Mohamed Hasan A.M. 2011. Design Optimazation of Savonius and Wells Turbines. Disertasi. University of Magdeburg, Magdeburg;

Sumiati. R. Juni 2012. Pengujian Turbin Angin Savonius Tipe U sudu di Lokasi Pantai Air Tawar Padang. Jurnal Teknik Mesin Politeknik Negeri Padang. Vol : 1(1). Hal : 26-32. Padang.

Zulfikar dkk. 2011. Kajian Eksperimental Pengaruh Jumlah Sudu Terhadap Torsi dan Putaran Turbin Savonius Type U. Jurnal Teknik Mesin Politeknik Negeri Padang. Vol : 8 (2). Hal : 1321. Padang.

Burcin Deda A. 2008. An Experimental study on improvement of a savonius rotor performance with curtaining. Experimental Thermal and Fluid Science. Vol : 32. Hal : 1637-1678.

Aji, Riangga. 2011. Pengaruh Variasi Tinggi Sudu Terhadap Performansi Vertikal Axis Wind Turbine Jenis Savonius Type- U. Tesis Jurusan 
Teknik Mesin Fakultas Teknik Universitas Brawijaya. Malang.

White F.M. 2005. Mekanika Fluida. Jilid 3. Edisi Kedua. Penerbit Erlangga, Jakarta.

Nakhoda Y.I. 2015. Rancang Bangun Kincir Angin Sumbu Vertikal Pembangkit Tenaga Listrik
Portabel. Seminar Nasional Sains dan Teknologi Terapan. Vol : 3. Hal : 59-67. Institut Teknologi Adhi Tama Surabaya. 